\title{
Extraction of Potassium from Microcline by Chlorination
}

\author{
Pablo Orosco ${ }^{1,3, *}$, Oriana Barrios ${ }^{2,3}$ and Manuel Ojeda ${ }^{2,3}$ \\ 1 Centro de Investigación y Desarrollo en Materiales Avanzados y Almacenamiento de Energía de \\ Jujuy (CIDMEJu), Av. Juan A. Rojas S/N, Jujuy Y4612, Argentina \\ 2 Instituto de Investigaciones en Tecnología Química (INTEQUI), Almirante Brown 1455, San Luis D5700, \\ Argentina; orianabarrios2511@gmail.com (O.B.); mojeda@unsl.edu.ar (M.O.) \\ 3 Facultad de Química, Bioquímica y Farmacia, Universidad Nacional de San Luis, Chacabuco y Pedernera, \\ San Luis D5700, Argentina \\ * Correspondence: pablorosco@gmail.com; Tel.: +54-3884-710926
}

Received: 11 March 2019; Accepted: 17 April 2019; Published: 15 May 2019

\begin{abstract}
A pyrometallurgical route for the extraction of potassium from microcline was investigated. The reagents used were microcline, calcite and chlorine gas. Isothermal and non-isothermal chlorination assays were performed using experimental equipment adapted for working in corrosive atmospheres. The effects of temperature and reaction time on the chlorination reaction of the microcline-calcite mixture were studied. The reaction mechanism was also investigated. The techniques used to characterize reagents and products were thermogravimetric analysis (TGA), $\mathrm{X}$-ray diffraction (XRD), scanning electron microscopy (SEM), and electron probe microanalysis (EPMA). The experimental results showed that the extraction of potassium in the form of $\mathrm{KCl}$ begins at $700{ }^{\circ} \mathrm{C}$ for $15 \mathrm{~min}$. Anorthite also starts to be produced under these conditions. The optimum conditions for quantitative extraction of potassium and selective formation of anorthite were $900{ }^{\circ} \mathrm{C}$ for $60 \mathrm{~min}$.
\end{abstract}

Keywords: extraction; potassium; chlorination; microcline; calcite

\section{Introduction}

Potassium is the third major plant and crop nutrient after nitrogen and phosphorus. This element plays an important role in a number of physiological processes essential to growth, development, stress resistance, yield, and quality of crops [1]. On Earth, potassium is the seventh most abundant element, comprising about $2.6 \%$ of the crust volume [2]. However, most of the potassium is incorporated in the crystal lattice structure of minerals and thus not directly available for plant uptake. By contrast, soluble potassium resources are scarce [3]. The most abundant $\mathrm{K}$-bearing minerals are microcline $\left(\mathrm{KAlSi}_{3} \mathrm{O}_{8}\right)$, muscovite $\left(\mathrm{KAl}_{3} \mathrm{Si}_{3} \mathrm{O}_{10}(\mathrm{OH})_{2}\right)$, and biotite $\left(\mathrm{K}(\mathrm{Mg}, \mathrm{Fe})_{3}\left(\mathrm{AlSi}_{3} \mathrm{O}_{10}\right)(\mathrm{OH})_{2}\right)$ [4].

Microcline is very difficult to decompose by conventional chemical methods due to the high stability of its structure [5]. Several methods have been developed to extract soluble potassium from microcline, including roasting [6,7], hydrothermal processes [8,9], bioleaching [10,11], and leaching $[5,12,13]$. However, these processes encounter some disadvantages such as high processing temperature, high energy consumption [6,7], generation of secondary phases during the process $[8,9]$, long reaction times $[10,11]$ or the requirement of expensive reagents and equipment $[5,12,13]$. Therefore, it is necessary to develop a simple, selective, and low-cost technique to extract soluble potassium from microcline. Previous work carried out in our research group on minerals chlorination using magnesium carbonate and chlorine gas showed that potassium chloride was extracted during chlorination of a microcline and hydromagnesite mixture, with forsterite and magnesium aluminate spinel being generated as well [14]. 
In this work, the chlorination of microcline using calcite and chlorine gas as reagents was studied with the purpose of extracting quantitative potassium and obtaining anorthite $\left(\mathrm{CaAl}_{2} \mathrm{Si}_{2} \mathrm{O}_{8}\right)$, a ceramic material used in electronic and refractory industries.

\section{Materials and Methods}

\subsection{Materials}

The minerals used in this work were microcline and calcite, both from San Luis, Argentina. The gases used in the different assays were chlorine gas 99.05\% $v / v$ (Cofil, Argentina) and nitrogen $99.99 \% v / v$ (AGA, Argentina). The mixture of the minerals, denominated Mi, was prepared in a ratio of $65 \% w / w$ of microcline and $35 \% w / w$ of calcite. The minerals were mixed in a disk mill for $4 \mathrm{~min}$. This ratio was selected, taking into account the reactivity of chlorine gas with calcite and microcline mixture. The reaction of Mi chlorination is represented by the following reaction:

$$
\mathrm{CaCO}_{3}+2 \mathrm{KAlSi}_{3} \mathrm{O}_{8}+\mathrm{Cl}_{2}(\mathrm{~g}) \rightarrow \mathrm{CaAl}_{2} \mathrm{Si}_{2} \mathrm{O}_{8}+2 \mathrm{KCl}+4 \mathrm{SiO}_{2}+\mathrm{CO}_{2}(\mathrm{~g})+0.5 \mathrm{O}_{2}(\mathrm{~g})
$$

The chemical composition of the minerals and the Mi sample are shown in Table 1. The crystalline phases present in Mi are shown in Figure 1.

Table 1. Chemical composition (\%w/w) of the starting minerals and the mixture of the minerals (Mi).

\begin{tabular}{cccc}
\hline & \multicolumn{2}{c}{ Mineral } & Sample \\
\cline { 2 - 4 } & Microcline & Calcite & Mi \\
\hline $\mathrm{Al}_{2} \mathrm{O}_{3}$ & 20.91 & - & 13.52 \\
$\mathrm{SiO}_{2}$ & 67.93 & - & 44.12 \\
$\mathrm{~K}_{2} \mathrm{O}$ & 10.28 & - & 6.72 \\
$\mathrm{CaO}$ & 0.18 & 55.94 & 19.58 \\
$\mathrm{Fe}_{2} \mathrm{O}_{3}$ & 0.68 & - & 0.42 \\
$\mathrm{LOI}$ & - & 44.02 & 14.36 \\
\hline
\end{tabular}

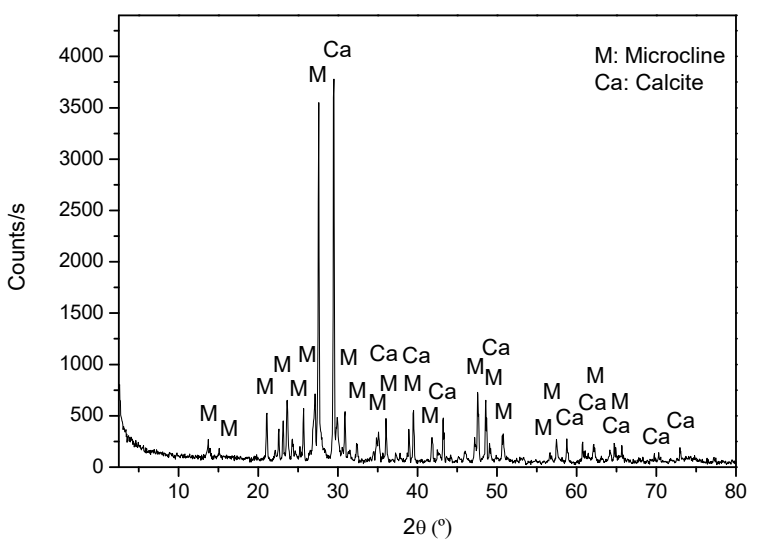

Figure 1. XRD pattern of the Mi sample.

Data on Table 1 indicates that the microcline used has a high degree of purity. In addition, this ore contained a high percentage of potassium.

The X-ray diffractogram (XRD) pattern of the minerals mixture shows the presence of two crystalline phases (microcline and calcite). SEM images of Mi sample are shown in Figure 2. The particles marked with the symbols $\square$ and $\bigcirc$ in Figure 2a,b were identified by electron probe microanalysis (EPMA) (Table 2) as microcline and calcite particles, respectively. The size of the particles of Mi sample is varied. Microcline has a particle size distribution from 3 to $20 \mu \mathrm{m}$ and calcite has a particle size distribution from 5 to $70 \mu \mathrm{m}$. 


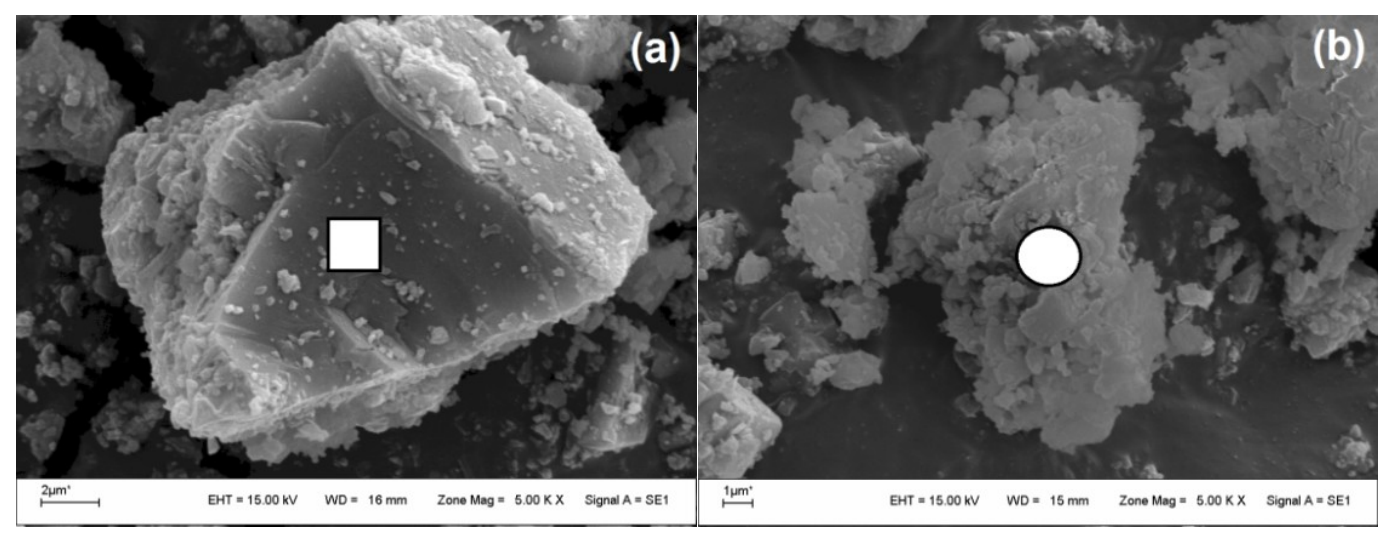

Figure 2. SEM micrographs corresponding to Mi sample: (a) microcline particle, (b) calcite particle.

Table 2. Electron probe microanalysis (\% atomic) corresponding to particles present in Mi sample.

\begin{tabular}{cccccc}
\hline Particle & Al & Si & Ca & K & O \\
\hline Microcline $(\square)$ & 10.32 & 34.73 & - & 8.71 & 46.23 \\
Calcite $(\bigcirc)$ & - & - & 38.62 & - & 46.86 \\
\hline
\end{tabular}

\subsection{Equipment}

The experimental chlorination assays were performed in a thermogravimetric system designed in our laboratory [15]. This device includes a quartz reactor placed inside an electric furnace equipped with a temperature controller.

The chemical composition of the minerals and the mixture, as well as the residues from thermal treatment of the mixture in chlorine, was determined by XRF using Philips PW 1400 X-ray equipment (Philips, Almelo, The Netherlands). The analysis by XRD on mixture and chlorination residues was performed on a Rigaku D-Max-IIIC (Rigaku Co., Tokyo, Japan), Cu-Ka, which was operated at 40 kV, $30 \mathrm{~mA}$.

\subsection{Calcination Procedure}

The assays in the thermogravimetric system were carried out using approximately $0.5 \mathrm{~g}$ masses of powder sample. For the thermal treatment, flows of $100 \mathrm{~mL} / \mathrm{min}$ of $\mathrm{Cl}_{2} / \mathrm{N}_{2}(50 \% v / v)$ were used.

\subsubsection{Procedure for Non-Isothermal Chlorination}

In each non-isothermal experiment, the samples were calcined in a gaseous mixture $\mathrm{Cl}_{2} / \mathrm{N}_{2}$ $(50 \% v / v)$ at a heating rate of $5{ }^{\circ} \mathrm{C} / \mathrm{min}$ until a temperature of $900{ }^{\circ} \mathrm{C}$ was reached. The mass change was recorded as a function of temperature.

\subsubsection{Procedure for Isothermal Chlorination}

In each isothermal assay, the sample was placed inside the reactor and calcined in a $\mathrm{N}_{2}$ atmosphere at a heating rate of $5{ }^{\circ} \mathrm{C} / \mathrm{min}$, until the working temperature was reached. Once this temperature was stabilized, $\mathrm{Cl}_{2}(\mathrm{~g})$ was fed into the reactor, generating the $\mathrm{Cl}_{2} / \mathrm{N}_{2}(50 \% \mathrm{v} / \mathrm{v})$ mixture. The sample was kept under this atmosphere during the reaction time. Subsequently, the $\mathrm{Cl}_{2}(\mathrm{~g})$ flow was interrupted, and the sample was purged with $\mathrm{N}_{2}$ while the reactor was cooled down.

The isothermal assays were conducted in the temperature range between 500 and $900{ }^{\circ} \mathrm{C}$ and periods of reaction from 15 to $120 \mathrm{~min}$. 


\subsubsection{Washing and Filtration of the Chlorination Residues}

The residues of these chlorination assays were subjected to washing and filtration with hot water in order to remove calcium chloride present in the chlorinated sample. The residues obtained were then dried in an oven at $100^{\circ} \mathrm{C}$. The washed and dried residues of filtration were analyzed by XRD.

\section{Results}

\subsection{Non-Isothermal Thermogravimetry in $\mathrm{Cl}_{2} / \mathrm{N}_{2}$}

The results of the non-isothermal treatment of the Mi sample in $\mathrm{Cl}_{2} / \mathrm{N}_{2}$ flow are shown in Figure $3 \mathrm{a}$. The thermogravimetric curve of the sample presents two mass change regions. The first region can be observed in a temperature range between 420 and $700{ }^{\circ} \mathrm{C}$, and corresponds to a mass gain of $2.9 \%$ approximately. The second region occurred in the range between 700 and $900{ }^{\circ} \mathrm{C}$, and is associated with a mass loss of approximately $2.3 \%$. This zone corresponds to a balance between mass gain and loss occurring in the sample as a consequence of phenomena taking place within this temperature interval.

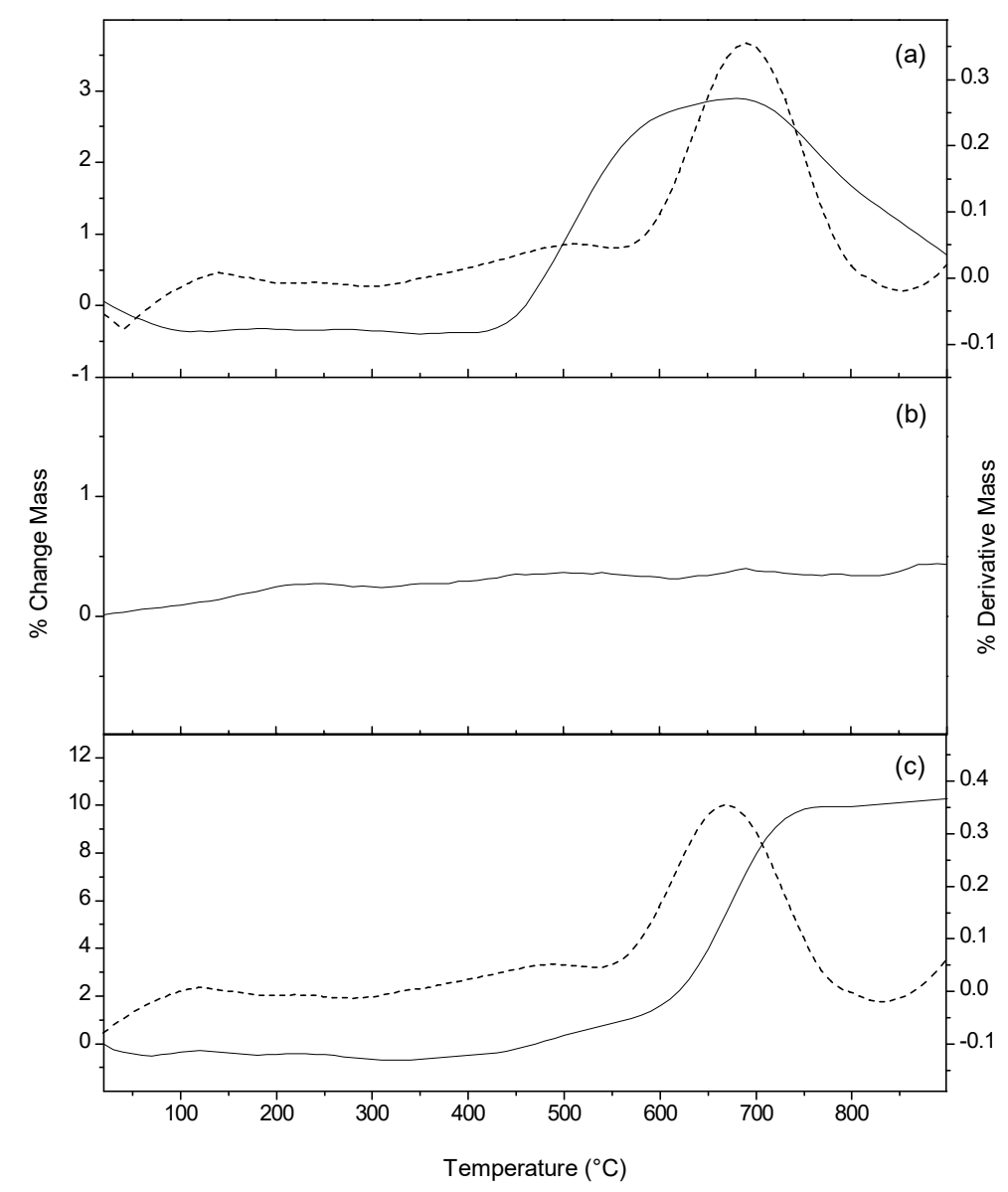

Figure 3. Thermogravimetric and derivative thermogravimetric curves corresponding to different samples calcined in $\mathrm{Cl}_{2}(\mathrm{~g})$ : (a) $\mathrm{Mi}$, (b) microcline and (c) calcite.

With the purpose of determining the phenomena that take place during the non-isothermal calcination of $\mathrm{Mi}$ in $\mathrm{Cl}_{2}(\mathrm{~g})$, non-isothermal chlorination assays of microcline and calcite, and isothermal chlorination assays of Mi at different temperatures for $15 \mathrm{~min}$ were carried out. The chlorination residues were then analyzed by XRD. 


\subsubsection{First Zone of Mass Change $\left(420-700^{\circ} \mathrm{C}\right)$}

The first region of mass loss observed in the thermogram of Figure 3a corresponds to the chlorination of calcite according to Reaction (2).

$$
\mathrm{CaCO}_{3}+\mathrm{Cl}_{2}(\mathrm{~g}) \rightarrow \mathrm{CaCl}_{2}+\mathrm{CO}_{2}(\mathrm{~g})+0.5 \mathrm{O}_{2}(\mathrm{~g})
$$

The occurrence of this reaction was demonstrated using the thermograms of calcite and microcline (Figure $3 \mathrm{~b}, \mathrm{c}$ ), and the XRD pattern corresponding to the chlorination residue of the Mi sample at $600{ }^{\circ} \mathrm{C}$ without the filtration and washing treatments (Figure 4).

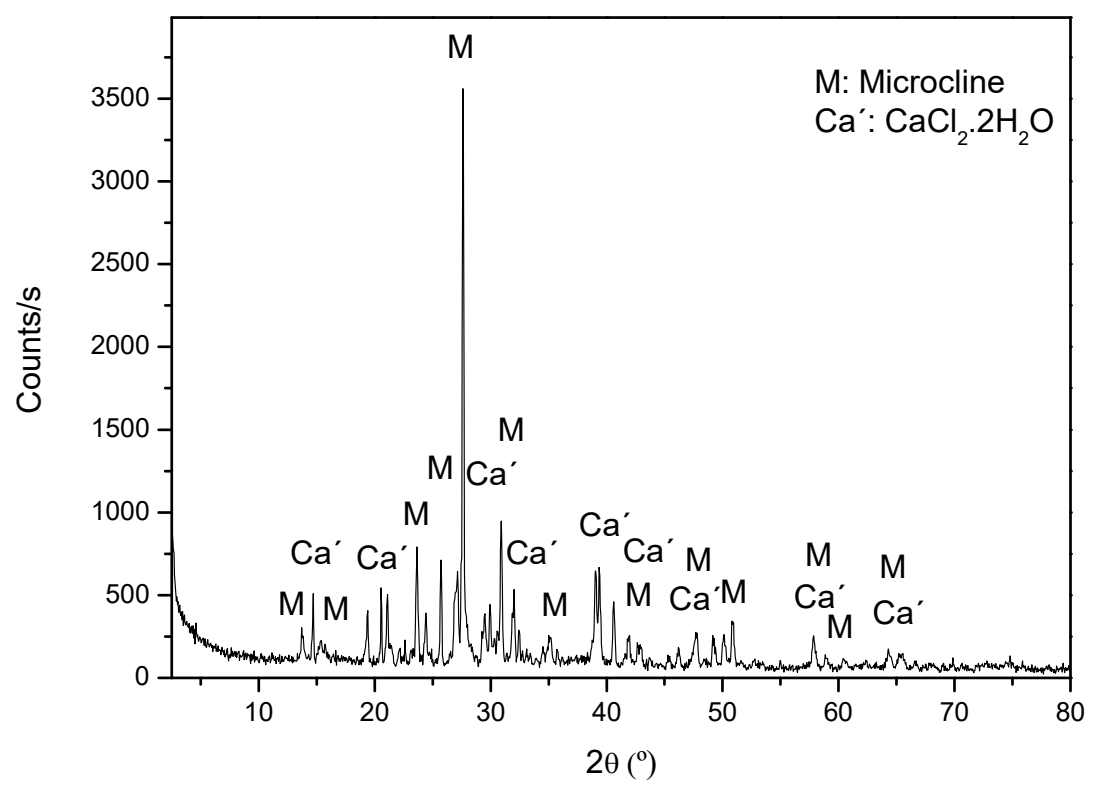

Figure 4. XRD pattern of the chlorination residue of the Mi sample at $600{ }^{\circ} \mathrm{C}$ for 15 min without filtration and washing treatments.

In the thermogram of microcline (Figure 3b) the mass remained constant, while in the thermogram of calcite (Figure 3c) a mass increase was observed, which was attributed to calcium chloride formation.

The XRD pattern of the untreated chlorination residue (Figure 4) shows the presence of microcline and calcium chloride, which are the product of calcite chlorination (Reaction (2)). This chloride is hydrated because it suffers a hydration process after being extracted from the reactor.

\subsubsection{Second Mass Change Zone $\left(700-900{ }^{\circ} \mathrm{C}\right)$}

The phenomena that occur in this region are described by the following Reaction (3):

$$
\mathrm{CaCl}_{2}+2 \mathrm{KAlSi}_{3} \mathrm{O}_{8} \rightarrow \mathrm{CaAl}_{2} \mathrm{Si}_{2} \mathrm{O}_{8}+2 \mathrm{KCl}+4 \mathrm{SiO}_{2}
$$

Potassium Extraction from Microcline

This phenomenon was corroborated using the thermograms of $\mathrm{Mi}$, microcline and calcite. Comparison of the thermogravimetric curves indicates that the mass remains constant between 700 and $900^{\circ} \mathrm{C}$ in the thermogram of microcline, while the thermograms of calcite and Mi showed mass gain and mass loss, respectively.

The behavior of mass with temperature in Figure $3 b$ indicates that chlorine gas does not react with microcline. The mass gain observed in Figure $3 \mathrm{c}$ was due to the formation of calcium chloride. The mass loss in Figure 3a was the result of a balance between the partial volatilization of $\mathrm{KCl}$ and the calcite chlorination (Reaction (2)). The volatilization of $\mathrm{KCl}$ was caused by the formation of a eutectic mixture between $\mathrm{KCl}$ and $\mathrm{CaCl}_{2}$ not consumed by Reaction (3). In the flow system used in this work, 
the volatile $\mathrm{KCl}$ generated was removed from the reaction zone, favoring the chlorination reaction of microcline, and the formation of more volatile $\mathrm{KCl}$.

Anorthite Synthesis from Microcline and Calcium Chloride

The calcium chloride produced by calcite chlorination (Reaction (2)) reacted with the microcline generating anorthite (Reaction (3)).

The reaction was experimentally proved by the XRD patterns of the residues corresponding to the calcined sample between 700 and $900{ }^{\circ} \mathrm{C}$ (Figure 5a-c). The figures show the anorthite, quartz and microcline phases, which confirms the proposed reaction mechanism for the synthesis of anorthite.

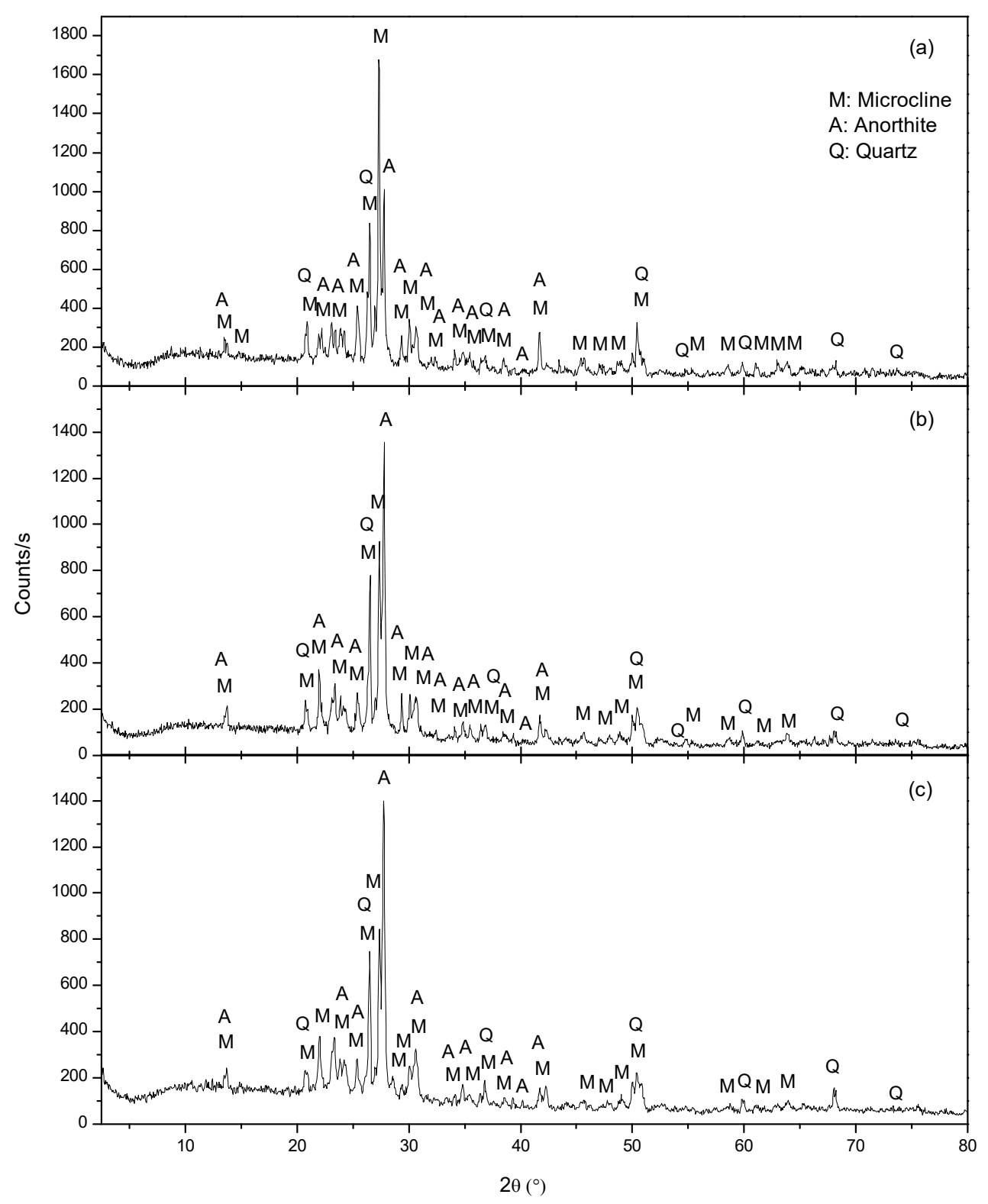

Figure 5. XRD patterns of the chlorination residue of the Mi sample at: (a) $700{ }^{\circ} \mathrm{C},(\mathbf{b}) 800{ }^{\circ} \mathrm{C},(\mathbf{c}) 900{ }^{\circ} \mathrm{C}$ and periods of $15 \mathrm{~min}$.

\subsection{XRF Analysis of $\mathrm{Mi}$ in $\mathrm{Cl}_{2} / \mathrm{N}_{2}$}

The results of the XRF analysis performed on sample Mi and the residues chlorinated at different temperatures and reaction times are presented in Figures 6 and 7. 


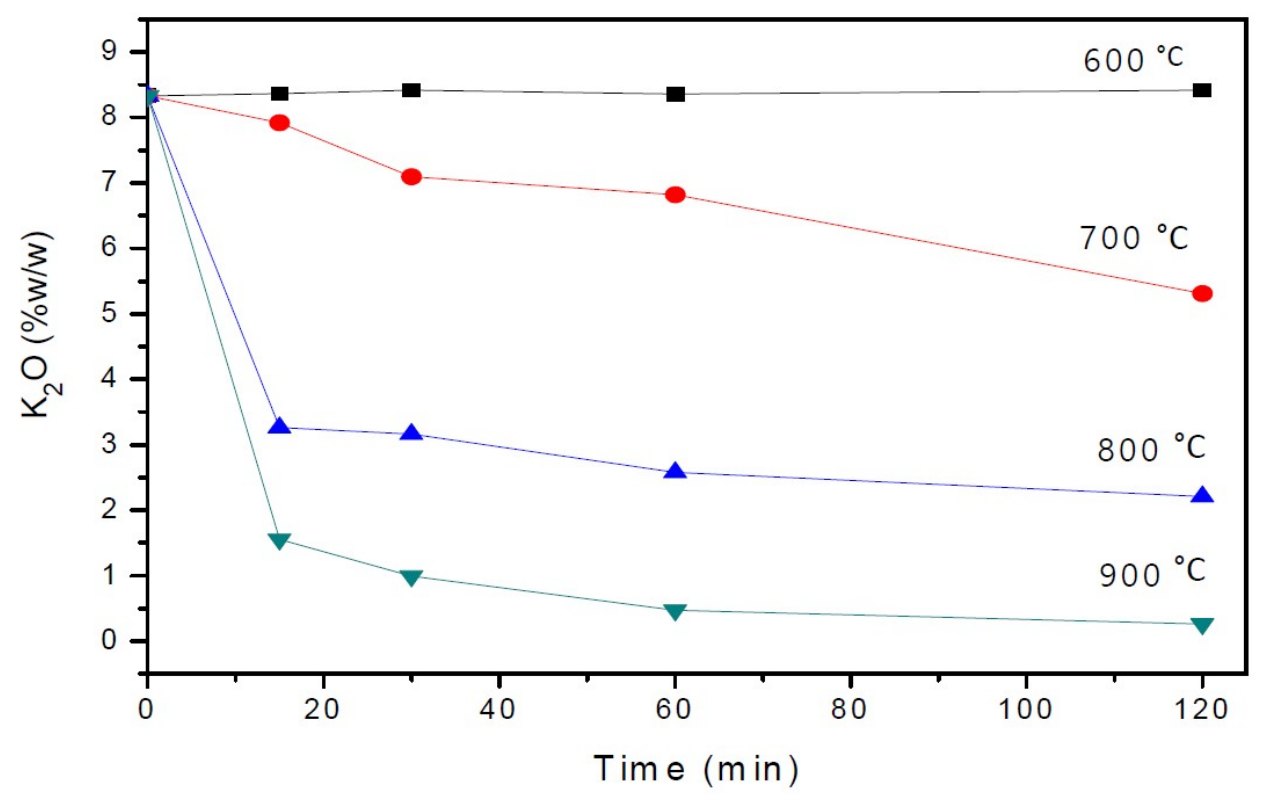

Figure 6. Content of $\mathrm{K}_{2} \mathrm{O}$ in residues of the $\mathrm{M} 1$ sample calcined in $\mathrm{Cl}_{2}(\mathrm{~g})$ at different temperatures and reaction times.

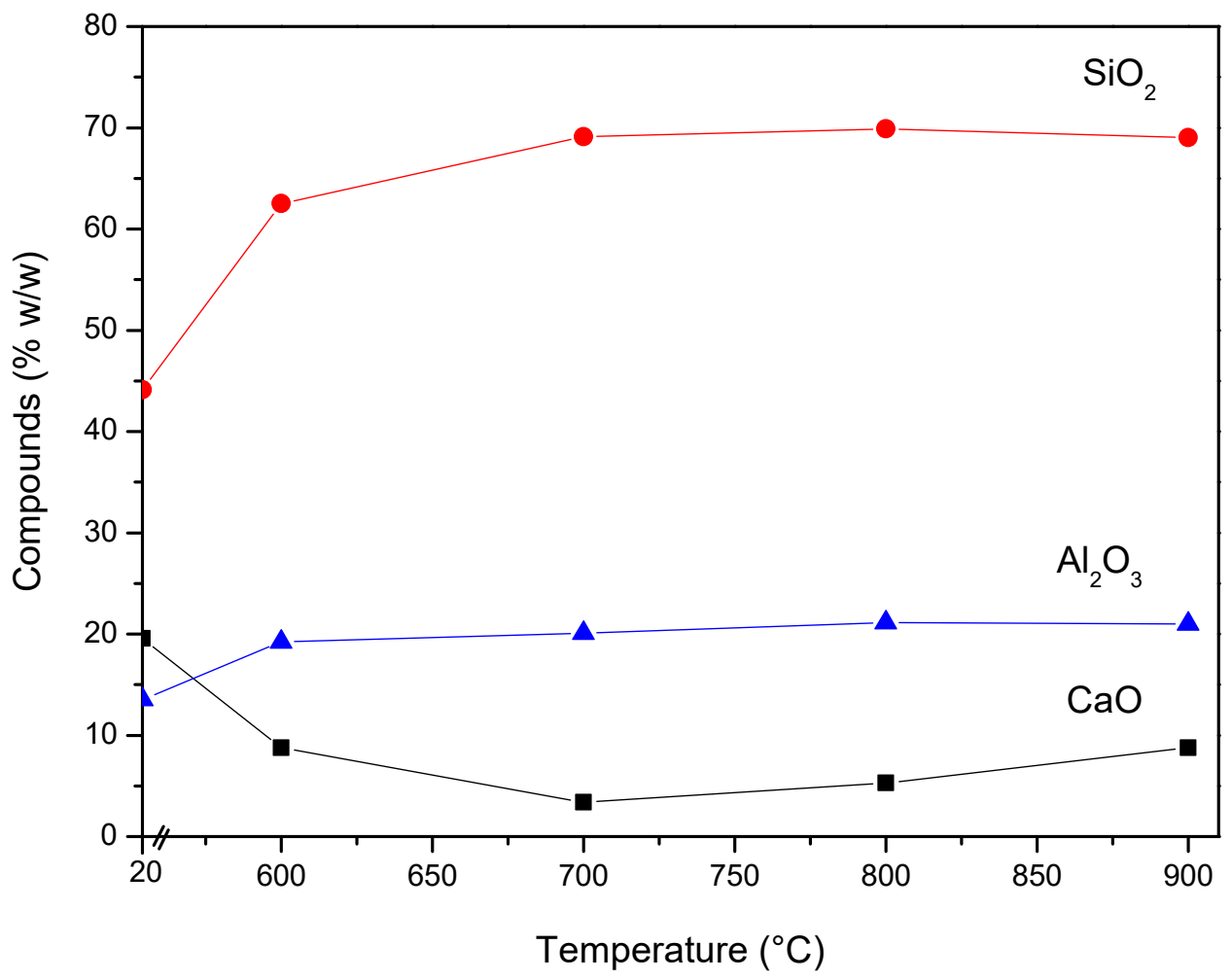

Figure 7. Content of $\mathrm{SiO}_{2}, \mathrm{Al}_{2} \mathrm{O}_{3}$ and $\mathrm{CaO}$ in residues of the Mi sample calcined in $\mathrm{Cl}_{2}(\mathrm{~g})$ at different temperatures for $120 \mathrm{~min}$.

The data shown in Table 1 and Figure 6 indicated that the content of potassium in the starting sample $(6.72 \% w / w)$ was less than the content of potassium in the chlorination residue calcined at $600^{\circ} \mathrm{C}(8.36 \% w / w)$. This is due to the fact that the $\mathrm{CaCl}_{2}$ not consumed by reaction (3) was removed by processes of washing and filtering, which generates a relative increase in the content of potassium in the residues. Therefore, comparison of the potassium content in the stoichiometric mixture without $\mathrm{CaCl}_{2}$ excess (Reaction (1)), which was $(8.33 \% w / w)$, with that in the chlorination residues is necessary to 
determine the starting temperature for potassium extraction. Thus, it could be inferred that potassium extraction starts at $700{ }^{\circ} \mathrm{C}$. It can be noted that a considerable increase in potassium extraction was produced in the temperature range between 700 and $800{ }^{\circ} \mathrm{C}$. These results can be attributed to the fact that $\mathrm{CaCl}_{2}$ (melting point $762{ }^{\circ} \mathrm{C}$ ) changes from solid to liquid state, which favors reaction (3). At $900{ }^{\circ} \mathrm{C}$ a quantitative recovery of potassium was produced, reaching an extraction extent of $97 \%$ $w / w$ for periods of $120 \mathrm{~min}$.

The figure also shows that the highest level of potassium extraction was produced at 800 and $900{ }^{\circ} \mathrm{C}$ during the first $15 \mathrm{~min}$.

In addition, the effect of chlorine gas and temperature on sample Mi causes changes in the concentration of $\mathrm{SiO}_{2}, \mathrm{Al}_{2} \mathrm{O}_{3}$ and $\mathrm{CaO}$ as shown in Figure 7. These changes are the result of a balance between mass gain and loss occurring in the sample as a consequence of the phenomena which take place during the chlorination. On the other hand, the process of washing and filtration carried out on chlorination residues after the thermal treatment affected the concentration of these compounds in $\mathrm{Mi}$. The chlorination residue of $\mathrm{Mi}$ at $600{ }^{\circ} \mathrm{C}$ showed an increase in the concentration of $\mathrm{SiO}_{2}$ and $\mathrm{Al}_{2} \mathrm{O}_{3}$ and a decrease in the concentration of $\mathrm{CaO}$ in relation to sample $\mathrm{Mi}$, which results from the removal by washing and filtering of the calcium chloride generated by Reaction (2). Between 700 and $900{ }^{\circ} \mathrm{C}$, the concentration of $\mathrm{CaO}$ increased significantly with temperature mainly due to the formation of anorthite. In this temperature interval, the concentration of $\mathrm{SiO}_{2}$ and $\mathrm{Al}_{2} \mathrm{O}_{3}$ remained constant, which is a consequence of two phenomena: the extraction of potassium from $\mathrm{Mi}$ and the anorthite synthesis.

\subsection{Conditions for Efficient Extraction of Potassium and Selective Formation of Anorthite}

The quantitative extraction of potassium from microcline was produced at $900^{\circ} \mathrm{C}$ for $60 \mathrm{~min}$ according to the data obtained by XRF (Figure 6).

Phase evolution during anorthite synthesis was investigated using the XRD patterns of chlorination residues at different temperatures and reaction times (Figure 8).

Figure 8 a,d show that anortithe formation in the presence of chlorine starts at $700{ }^{\circ} \mathrm{C}$ and continue until the final investigated temperature. This can be inferred by comparing the XRD patterns of the chlorination residues of the Mi sample obtained between 700 and $900{ }^{\circ} \mathrm{C}$ and different periods of time, since the intensity of typical peaks of anorthite increases with temperature.

The disappearing of typical peaks of microcline occurred at $900{ }^{\circ} \mathrm{C}$ for $60 \mathrm{~min}$ (Figure 8c) and a significant crystallization of anorthite was observed at $900^{\circ} \mathrm{C}$ for $120 \mathrm{~min}$ (Figure 8d). This indicates that anorthite formation is selective at $900^{\circ} \mathrm{C}$ for the time period range of 60 to $120 \mathrm{~min}$.

SEM micrographs of the anorthite obtained at $900^{\circ} \mathrm{C}$ and a reaction time of $60 \mathrm{~min}$ are shown in Figure 9. In the SEM image of Figure $9 \mathrm{a}$, a large number particles of irregular shape and varied size can be observed. Figure $9 \mathrm{~b}$ reveals that anorthite particles are porous.

The obtained results indicate that the optimum conditions of chlorination for the extraction of potassium from microcline and synthesizing anorthite is $900{ }^{\circ} \mathrm{C}$ for $60 \mathrm{~min}$, while for longer periods of time a significant recovery of potassium was not observed and for shorter periods of time anorthite was not selectively formed.

With the aim of determining the effect of $\mathrm{CaCl}_{2}$ on microcline, a calcination assay of a mixture microcline/ $\mathrm{CaCl}_{2}$ in a ratio $65 / 35(\% w / w)$ at $900{ }^{\circ} \mathrm{C}$ for $60 \mathrm{~min}$, in $\mathrm{N}_{2}(100 \mathrm{~mL} / \mathrm{min})$ was carried out. The XRD pattern of the calcined mixture is shown in Figure 10. 


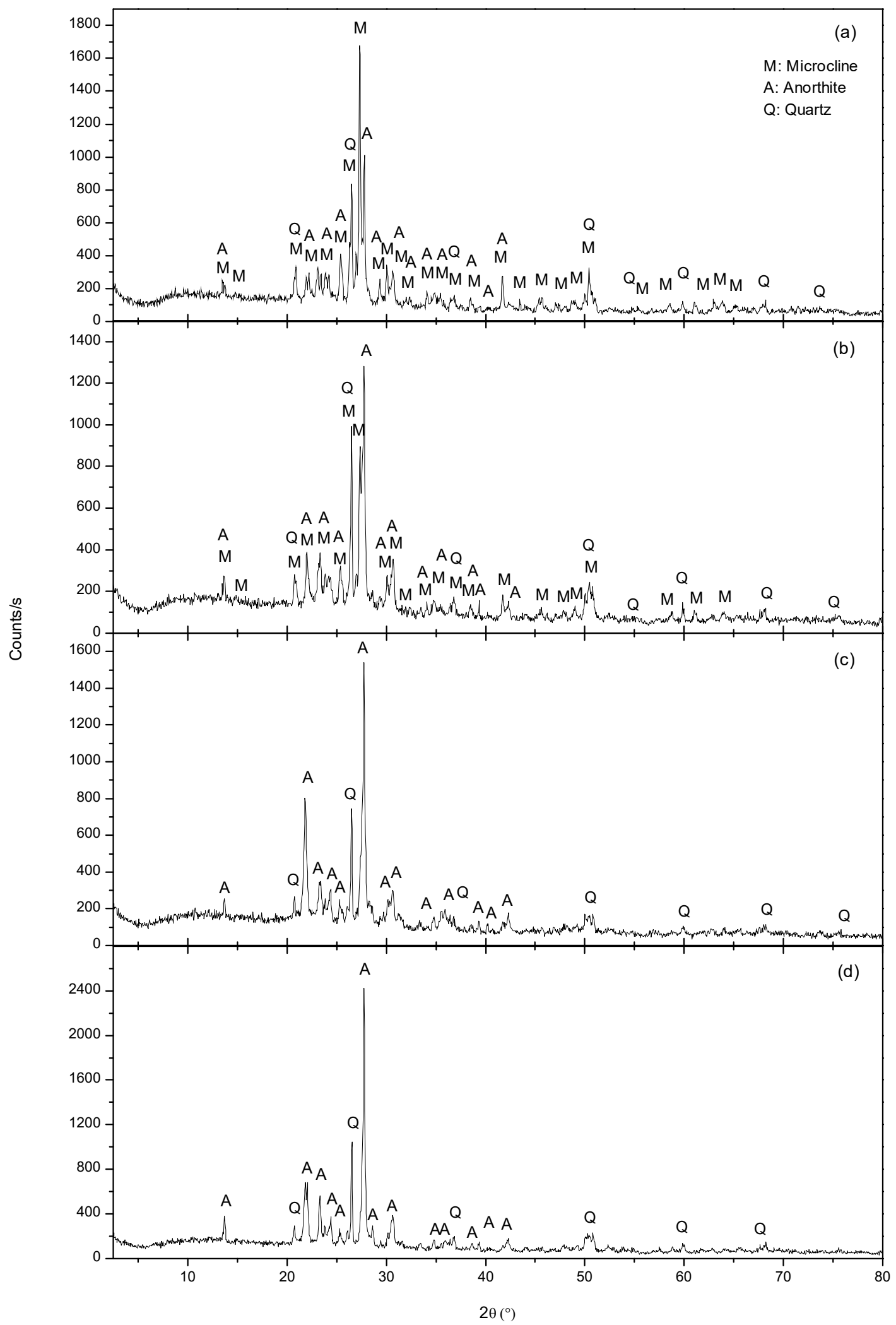

Figure 8. XRD patterns of Mi sample calcined in $\mathrm{Cl}_{2}$ (g): (a) $700{ }^{\circ} \mathrm{C}$ for $15 \mathrm{~min}$, (b) $800{ }^{\circ} \mathrm{C}$ for $60 \mathrm{~min}$, (c) $900{ }^{\circ} \mathrm{C}$ for $60 \mathrm{~min},(\mathrm{~d}) 900{ }^{\circ} \mathrm{C}$ for $120 \mathrm{~min}$. 

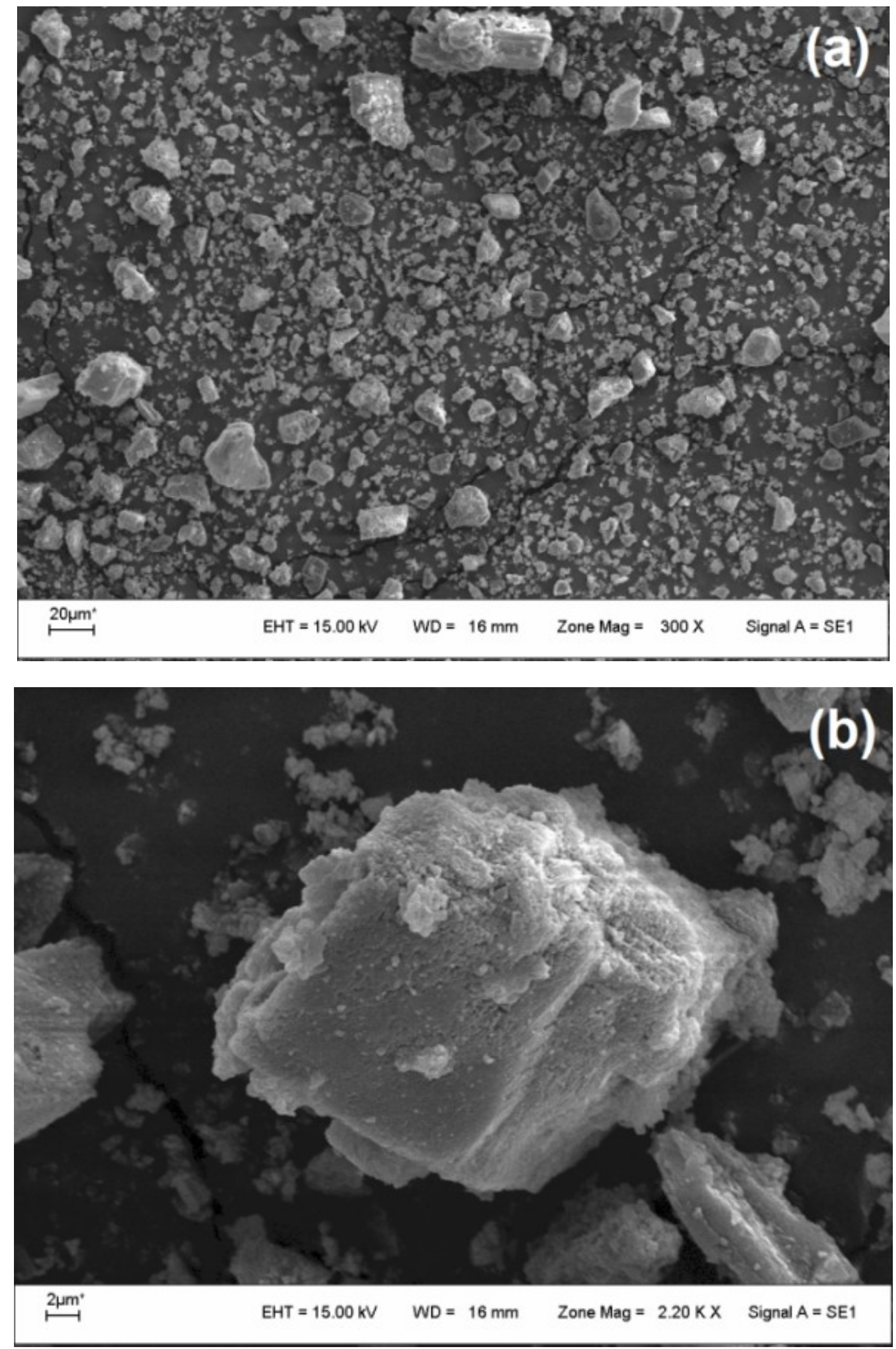

Figure 9. SEM micrographs of the anorthite obtained at $900{ }^{\circ} \mathrm{C}$ for $60 \mathrm{~min}$ : (a) overall view, (b) anorthite particle. 


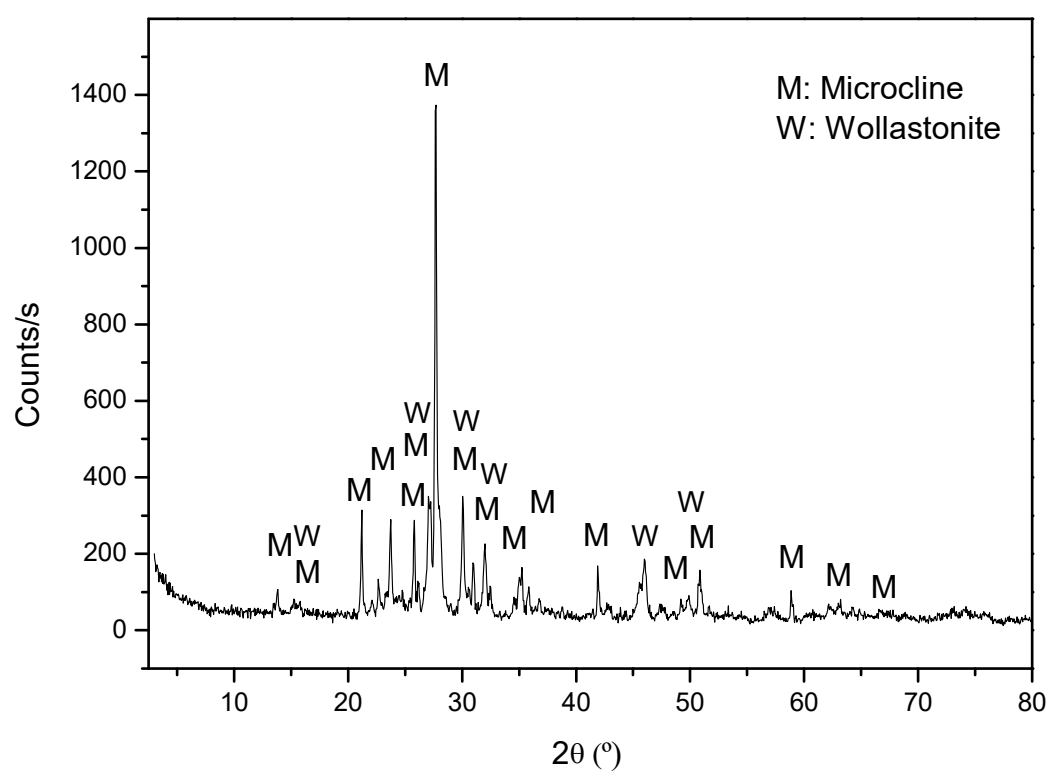

Figure 10. XRD pattern of the chlorination residue of the mixture $\mathrm{KAlSi}_{3} \mathrm{O}_{8} / \mathrm{CaCl}_{2}$ calcined in $\mathrm{N}_{2}$ at $900^{\circ} \mathrm{C}$ for $60 \mathrm{~min}$.

This figure shows the presence of microcline and wollastonite $\left(\mathrm{CaSiO}_{3}\right)$. The high intensity of microcline characteristic peaks and low intensity of wollastonite typical peaks indicate that the calcination of microcline with $\mathrm{CaCl}_{2}$ is not efficient method to extract potassium and produce new phases.

\section{Conclusions}

The results of the chlorination assays of a mixture containing microcline and calcite in a ratio of $65 / 35(\% w / w)$ prove that this process is an efficient method for the extraction of potassium from microcline and the synthesis of anorthite at moderate temperatures.

Potassium in the form of $\mathrm{KCl}$ is extracted from microcline in the temperature interval between 700 and $900{ }^{\circ} \mathrm{C}$. At $900{ }^{\circ} \mathrm{C}$ for $120 \mathrm{~min}$ the extraction extent of potassium was about $97 \% \mathrm{w} / \mathrm{w}$.

The formation of anorthite in $\mathrm{Cl}_{2}(\mathrm{~g})$ atmosphere started at $700^{\circ} \mathrm{C}$ for $15 \mathrm{~min}$ and was totally selective at $900{ }^{\circ} \mathrm{C}$ for $60 \mathrm{~min}$.

The most favorable chlorination conditions for the extraction of potassium from microcline and synthesis of anorthite were $900^{\circ} \mathrm{C}$ and $60 \mathrm{~min}$ reaction time. These conditions allowed for efficient extraction of potassium and selective formation of anorthite.

Author Contributions: Conceptualization, P.O., O.B. and M.O.; Methodology, P.O. and M.O.; Validation, P.O. and O.B.; Investigation, P.O.; Resources, P.O., O.B. and M.O.; Data Curation, P.O.; Writing-Original Draft Preparation, P.O. and O.B.; Writing-Review \& Editing, P.O. and M.O.; Visualization, P.O.; Supervision, P.O.; Project Administration, P.O.; Funding Acquisition, P.O and M.O.

Funding: This research received no external funding and the APC was funded by Universidad Nacional de San Luis (UNSL), and Consejo Nacional de Investigaciones Científicas y Técnicas (CONICET).

Acknowledgments: The authors wish to thank Universidad Nacional de San Luis (UNSL), and Consejo Nacional de Investigaciones Científicas y Técnicas (CONICET) for the financial support and Instituto de Lenguas of Universidad Nacional de San Luis for language revision.

Conflicts of Interest: The authors declare no conflict of interest. The funders had no role in the design of the study; in the collection, analyses, or interpretation of data; in the writing of the manuscript, and in the decision to publish the results. 


\section{References}

1. Meena, V.S.; Maurya, B.R.; Verma, J.P.; Meena, R. Potassium Solubilizing Microorganisms for Sustainable Agriculture; Springer: Berlin, Germany, 2016; pp. 40-41.

2. Lal, R. Encyclopedia of Soil Science, 2nd ed.; CRC Press: New York, NY, USA, 2006; p. 1359.

3. Panpatte, D.G.; Jhala, Y.K.; Vyas, R.V.; Shelat, H.N. Microorganisms for Green Ch. Zörba, M. Senbayram, Peiter, E. Potassium in agriculture-Status and perspectives. J. Plant Physiol. 2014, 171, 656-669.

4. Nieder, R.; Benbi, D.K.; Reichl, F.X. Soil Components and Human Health; Springer: Berlin, Germany, 2018; p. 269.

5. Maa, J.; Zhang, Y.; Qin, Y.; Wu, Z.; Wang, T.; Wang, C. The leaching kinetics of K-feldspar in sulfuric acid with the aid of ultrasound. Ultrason. Sonochem. 2017, 35, 304-312. [CrossRef]

6. Qiu, L.H.; Wang, L.S.; Jin, Z.M. Leaching process of potassium sulfate from roasts of potash feldspar, gypsum and calcium carbonate. J. Chem. Eng. Chin. Univ. 2000, 14, 465-469.

7. Feng, W.W.; Ma, H.W. Thermodynamic analysis and experiments of thermal decomposition for potassium feldspar at intermediate temperatures. J. Chin. Ceram. Soc. 2004, 32, 789-799.

8. $\quad$ Long, G.Y.; Yue, H.R.; Wang, Y.F.; Sheng, Y.H.; Yuan, B.; Lu, L.; Li, C.; Zhu, B.L.; Ma, H.W.; Su, S.Q.; et al. Preparation of potassium sulfate from K-feldspar by hydrothermal alkaline method: Reaction principle and process evaluation. CIESC J. 2014, 65, 2363-2371. (In Chinese)

9. Su, S.Q.; Ma, H.W.; Chuan, X.Y. Hydrothermal decomposition of K-feldspar in $\mathrm{KOH}-\mathrm{NaOH}-\mathrm{H}_{2} \mathrm{O}$ medium. Hydrometallurgy 2015, 156, 47-52. [CrossRef]

10. Yi, L.B.; Peng, Q.Z.; He, Q.Z.; Peng, Q.J. Isolation and identification of potash fields solubilizing bacteria and their potassium-releasing activities. Chin. J. Microecol. 2012, 24, 773-776, 785.

11. Bhattacharya, S.; Bachani, P.; Jain, D.; Patidar, S.K.; Mishra, S. Extraction of potassium from K-feldspar through potassium solubilization in the halophilic Acinetobacter soli (MTCC 5918) isolated from the experimental salt farm. Int. J. Miner Process. 2016, 152, 53-57. [CrossRef]

12. Ji, H.P.; Xu, J.M. Research progress of potassium extraction from potash feldspar. Mod. Chem. Ind. 2011, 31, 30-33.

13. Chen, T.P.; Han, X.Z.; Zheng, Y.X.; Li, W.; Fang, D.M.; Zheng, B.C. Study on ball milling reaction process based on potash feldspar-phosphate rocks hydrochloric acid system. Chem. Miner. Process. 2013, 1, 1-4.

14. Orosco, P.; Ruiz, M.D.C. Potassium chloride production by microcline chlorination. Thermochim. Acta 2015, 613, 108-112. [CrossRef]

15. Túnez, F.M.; González, J.; Ruiz, M.D.C. Aparato de Laboratorio para Realizar Termogravimetrías en Atmósferas Corrosivas y no Corrosivas. AR Patent 053676 A1, P060100450, 2007. 